\title{
Efektivitas Permainan Tradisional Gobag Sodor Terhadap Hasil Belajar Subtema 3 Keseimbangan Ekosistem
}

\author{
Nanda Yunita Sari ${ }^{1}$, Ferina Agustini ${ }^{2}$, Moh. Aniq KHB ${ }^{3}$ \\ 1,2,3 Jurusan PGSD, Universitas PGRI, Semarang, \\ e-mail: Nandayunitasari17@gmail.com
}

\begin{abstract}
ABSTRAK
Rendahnya hasil belajar tematik kelas $\mathrm{V}$ merupakan hal yang mendorong dalam penelitian ini. Hal tersebut dikarenakan minat dan motivasi belajar kurang, sehingga membuat siswa kurang aktif. Tujuan yang hendak dicapai adalah mengetahui efektivitas Permainan Tradisional Gobag Sodor terhadap hasil belajar subtema 3 Keseimbangan Ekosistem siswa Kelas V SD N Wonolopo 02, dilihat dari hasil belajar dan ketuntasan belajar. Adapun hasil belajar yang diteliti yaitu hasil belajar kognitif, afektif, dan psikomotorik. Metode penelitian ini adalah penelitian kuantitatif dalam bentuk PreeExperimental Design, dengan rancangan One-Group Pre-test-Post-test Design. Teknik yang digunakan yaitu Sampling Jenuh. Teknik tersebut adalah teknik penentuan sampel, bila semua anggota populasi digunakan sebagai sampel. Dari hasil penelitian, menunjukkan bahwa 1) terdapat perbedaan pretest dan posttes dibuktikan dengan hasil uji t thitung sebesar 5,903018 > ttabel 1,684 pada taraf signifikan 5\%,2) Rata-rata nilai sikap dan keterampilan siswa juga meningkat dengan menggunakan permainan tradisional gobag sodor, 3) Ketuntasan belajar individu dilihat dari nilai posttest lebih baik dari nilai pretest, terdapat 31 siswa tuntas, dan 5 siswa yang belum tuntas. Ketuntasan belajar klasikal mencapai $86,11 \%$. Dari hasil penelitian tersebut, dapat disimpulkan bahwa permainan tradisional gobag sodor efektif terhadap hasil belajar subtema 3 keseimbangan ekosistem siswa Kelas V SD N Wonolopo 02.
\end{abstract}

Kata Kunci: Permainan Tradisional Gobag Sodor, Pembelajaran Tematik, Hasil Belajar

\begin{abstract}
The low grade $V$ thematic learning outcomes are the things that are encouraging in this study. This is due to lack of learning interest and motivation, thus making students less active. The aim to be achieved is to know the effectiveness of the Gobag Sodor Traditional Game on the learning outcomes of the 3 Ecosystem Balance sub-theme of Grade V students of SD N Wonolopo 02, seen from the results of learning and completeness of learning. The learning outcomes studied are cognitive, affective, and psychomotor learning outcomes. The method of this research is quantitative research in the form of Pree-Experimental Design, with the design of One-Group Pre-test-Post-test Design. The technique used is Saturated Sampling. The technique is a sampling technique, if all members of the population are used as samples. From the results of the study, it shows that 1) there are differences in pretest and posttest proven by the results of the t-test of 5.903018> ttable 1.684 at the significance level of $5 \%$,2) The average value of students' attitudes and skills also increases using traditional gobag sodor , 3) Individual learning completeness seen from the posttest value is better than the pretest value, there are 31 students complete, and 5 students who have not finished. Classical learning completeness reaches $86.11 \%$. From the results of these studies, it can be concluded that the traditional gobag sodor game is effective against the learning outcomes of the sub-theme 3 of the ecosystem balance of Class V students of SD N Wonolopo 02.
\end{abstract}

Kata Kunci: Permainan Tradisional Gobag Sodor, Pembelajaran Tematik, Hasil Belajar 


\section{Pendahuluan}

Dalam proses pendidikan, terdapat 2 yang utama, yaitu guru dan siswa. Guru sebagai pembelajar melibatkan siswa untuk aktif dalam membangun pengetahuan, sikap dan perilaku, sehingga mereka memperoleh pemahaman mendalam yang dapat meningkatkan mutu kualitas.

Berdasarkan UU Sisdiknas No. 20 Tahun 2003, Pasal 1 ayat 19, bahwa untuk memperbaiki mutu pendidikan di Indonesia, maka pemerintah menyusun kurikulum yang berfungsi sebagai pedoman dalam pelaksanaan kegiatan pembelajaran. Kurikulum adalah seperangkat rencana dan pengaturan mengenai tujuan, isi, serta cara yang digunakan sebagai pedoman penyelenggaraan kegiatan pembelajaran untuk mencapai tujuan pendidikan tertentu. Kurikulum 2013 berbasis kompetensi dan karakter, diharapkan dapat membekali peserta didik dengan berbagai kemampuan sesuai dengan tuntutan zaman, serta perkembangan teknologi dan seni, guna menjawab tantangan arus globalisasi. Dengan diterapkannya kurikulum 2013, terjadi perubahan yang dulunya menggunakan mata pelajaran berubah menjadi pembelajaran tematik integratif. Guru diharuskan membuat pembelajaran menjadi lebih menarik, efektif, dan menyenangkan.

Peraturan Menteri Pendidikan dan Kebudayaan nomor 22 Tahun 2016 menjelaskan bahwa proses pembelajaran pada satuan pendidikan diselenggarakan secara interaktif, inspiratif, menyenangkan dan menantang. Pembelajaran yang menyenangkan dan menantang dapat diwujudkan dengan melibatkan siswa secara langsung dalam berbagai jenis kegiatan pembelajaran di dalam maupun di luar kelas. Oleh karena itu pembelajaran yang dilakukan harus membuat siswa lebih aktif dalam memahami materi guna memperoleh hasil yang memuaskan.

Kegiatan belajar mengajar melibatkan guru dan siswa. Guru menciptakan pembelajaran yang bermakna dengan siswa belajar mengetahui, belajar melakukan sesuatu, dan bersosialisasi dengan teman. Sehingga siswa terjalin baik antara individu dan kelompok. Kegiatan belajar mengajar merupakan inti daripada kegiatan pendidikan, dimana segala sesuatunya telah diprogramkan dan akan dilaksanakan dalam proses pembelajaran. Guru yang memprogramkan dan siswa yang melaksanakan.

Dalam kegiatan pembelajaran, guru harus memperhatikan minat belajar siswa supaya tujuannya dapat tercapai. Minat sangat besar pengaruhnya terhadap belajar, karena bila bahan pelajaran yang dipelajari tidak sesuai dengan minat, maka tidak akan belajar dengan sebaik-baiknya. Selain itu minat belajar erat hubungannya dengan hasil belajar. Apabila minat belajar siswa tinggi, maka hasil belajar pun akan tinggi, sebaliknya jika minat belajar rendah maka hasil belajar pun kurang maksimal.

Berdasarkan hasil wawancara dengan guru kelas V, Ibu F.Titi Lestari di SD $\mathrm{N}$ Wonolopo 02, bahwa minat dan hasil belajar siswa kelas $\mathrm{V}$ masih kurang. Saat ini guru sudah menggunakan banyak metode, namun hasil belajarnya masih kurang memuaskan yaitu belum mencapai nilai KKM yang ditentukan sebesar 70 . Selain itu saat pembelajaran, siswa masih kurang aktif.

Rendahnya minat belajar dan hasil belajar siswa ini, dikarenakan banyak hal, seperti yang sudah disampaikan guru, bahwa dalam penyampaian materi, sudah ada variasi metode maupun model yang digunakan guru saat mengajar, namun hasilnya masih belum memuaskan. Saat ini, siswa belum sepenuhnya aktif serta cenderung cepat merasa bosan dengan pembelajaran, dan lebih memilih asyik bermain sendiri. Motivasi orang tua dari siswa juga masih kurang, karena kebanyakan orang tua siswa bekerja, dan mempasrahkan segalanya ke guru, padahal mereka membutuhkan motivasi untuk meningkatkan hasil belajar supaya optimal. Selain itu pembelajaran masih berpusat di dalam kelas, siswa belum di ajak untuk belajar di luar kelas. Pembelajaran yang dilakukan di dalam kelas secara terus menerus dapat menimbulkan rasa bosan. Siswa membutuhkan perubahan lingkungan baru, yang berfungsi sebagai tempat belajar, adapun salah satunya dengan bermain.

Ada berbagai macam metode dan model yang dapat dimanfaatkan dalam pelaksanaan proses belajar-mengajar, namun tetap harus memperhatikan pribadi anak sebagai pemangku hak asasi manusia, yaitu anak yang bebas dan berakal budi. Menurut Soegeng 
(2018: 306), bahwa proses pembelajaran yang membebaskan berarti proses pembelajaran yang memberi kesempatan yang seluas-luasnya bagi pertumbuhan dan perkembangan anak, memungkinkan inisiatif, kreasi, inovasi, dan eksplorasi untuk anak menemukan jatidiri, sebagai dirinya sendiri, secara bebas, sesuai dengan pilihan bebasnya.

Bermain merupakan cara anak, untuk memperoleh pengetahuan tentang segala sesuatu. Menurut (Kurniati, 2016:4), bahwa bermain akan menumbuhkan anak untuk melakukan eksplorasi, melatih pertumbuhan fisik, memberikan peluang yang luas untuk berinteraksi dengan orang dewasa, mengembangkan kemampuan berbahasa, menambah kata-kata, serta membuat belajar yang dilakukan sebagai belajar yang sangat menyenangkan.

Hal tersebut senada dengan pendapat Santrock dalam (Kurniati, 2016:4) mengemukakan bahwa permainan mampu meningkatkan afiliasi dengan teman sebaya, mengurangi tekanan, meningkatkan perkembangan kognitif, meningkatkan daya jelajah dan memberi tempat berteduh yang aman bagi perilaku yang secara potensial berbahaya. Dengan bermain, anak-anak akan berbicara dan berinteraksi dengan satu sama lain.

Perkembangan bermain yang digunakan dalam pembelajaran, tentunya disesuaikan dengan kemampuan siswa, yaitu dari bermain sambil belajar menjadi belajar sambil bermain. Menurut Solehuddin, dalam (Kurniati, 2016:8), untuk mengimplementasikan secara langsung, bermain bisa digunakan sebagai metode pembelajaran bagi siswa.

Dalam hal ini, permainan tradisional gobag sodor dapat diterapkan sebagai sarana untuk penyampaian materi selain model ataupun metode yang digunakan guru saat proses pembelajaran. Dengan permainan tradisional gobag sodor membuat siswa lebih aktif dalam pembelajaran. Permainan tradisional gobag sodor dapat membantu guru dalam mendesain pembelajaran, sehingga menjadi lebih menarik dan menyenangkan.

Permainan tradisional gobag sodor adalah permainan kelompok yang terdiri dari 2 kelompok, dengan jumlah pemain harus genap, antara 6-10 orang masing-masing kelompok beranggotakan 5 orang (Achroni, 2012:55). Menurut (Linggar, 2010:30), permainan gobag sodor dikenal di daerah Jawa Tengah, Galah dikenal di daerah Kepulauan Natuna, dan Jawa Barat dikenal dengan Galah Asin. Jadi dapat disimpulkan bahwa, permainan tradisional gobag sodor adalah permainan kelompok yang beranggotakan 6-10 orang, dengan maju mundur melalui pintu-pintu Melalui permainan tradisional gobag sodor yang sudah dimodifikasi ini, dapat meningkatkan hasil belajar siswa kelas V.

Hal tersebut diperkuat oleh penelitian yang tersusun di dalam jurnal, oleh Arief Rahman Hakim dalam penelitian yang berjudul "Efektivitas Permainan Tradisional Gobag Sodor untuk Pembelajaran IPS Kelas IV Sekolah Dasar" Tahun 2017 Hasil penelitian ini, terdapat perbedaan hasil belajar antara kelas kontrol pembelajaran tanpa menggunakan permainan gobag sodor, dan kelas eksperimen diberi perlakuan, yaitu pembelajaran dengan permainan gobag sodor, dengan nilai ttest diperoleh thitung $=2,999$ untuk ttabel dengan $\mathrm{df}=1,677$. Sehingga thitung $>$ ttabel yaitu 2,999 >1,677. Dari hasil penelitian dapat disimpulkan bahwa penggunaan permainan tradisional gobag sodor efektif untuk meningkatkan hasil belajar IPS siswa KELAS IV SDN Putat Kidul 02. Jika permainan tradisional gobag sodor diterapkan , dapat memotivasi siswa dalam belajar karena menarik dan menyenangkan bagi siswa. Selain itu melalui bermain, mereka akan mudah memahami konsep yang dipelajari, sehingga hasil belajar akan meningkat.

Berdasarkan pemaparan di atas, maka dalam penelitian ini diteliti mengenai efektivitas permainan tradisional gobag sodor untuk meningkatkan hasil belajar subtema 3 Keseimbangan Ekosistem kelas V SD N Wonolopo 02.

Tujuan penelitian ini adalah untuk mengetahui evektivitas permainan tradisional gobag sodor terhadap hasil belajar subtema 3 Keseimbangan Ekosistem Kelas V SD N Wonolopo 02.

\section{Metode}

Jenis penelitian yang digunakan dalam penelitian ini adalah penelitian kuantitatif dengan menggunakan desain eksperimen tipe Pre Experimental. Desain yang digunakan 
dalam penelitian ini adalah desain Satu Kelompok Pretest-Postest (One Group PretestPosttest). Penelitian ini dilakukan di SD N Wonolopo 02.

Dalam desain ini, sebelum perlakuan terlebih dahulu sampel diberi pretest dan di akhir pembelajaran sampel diberi posttest. Pada awal kegiatan pembelajaran, siswa akan diberikan tes (pretest) untuk mengetahui kemampuan awal siswa terhadap materi subtema 3 Keseimbangan Ekosistem. Kemudian siswa diberikan treatment berupa pembelajaran dengan menggunakan permainan tradisional gobag sodor. Setelah diberikan treatment, di akhir pembelajaran siswa diberikan tes (posttest) untuk mengetahui kemampuan akhir siswa.

Populasi dalam penelitian ini adalah siswa kelas V SD N Wonolopo 02. Sedangkan sampel yang diambil adalah siswa kelas $\mathrm{V}$ yang terdiri dari 17 laki-laki dan 19 perempuan. Teknik sampel dalam penelitian ini adalah teknik Non Probability Sampling, dengan jenis Sampling Jenuh. Dalam penelitian ini, sampel dan populasi yang digunakan yaitu siswa kelas V SD N Wonolopo 02.

Teknik analisis data yang digunakan dalam penelitian ini adalah uji normalitas awal menggunakan pretest, uji normalitas akhir menggunakan posttest, dan uji hipotesis menggunakan uji t. Adapun hipotesis penelitiannya yaitu :

Ho : Tidak terdapat perbedaan nilai pretest dan posttest yang diperoleh setelah menggunakan permainan tradisional gobag sodor, dengan thitung $>$ ttabel.

$\mathrm{Ha}$ : Ada perbedaan nilai nilai prettest dan posttest yang diperoleh setelah menggunakan permainan tradisional gobag sodor, dengan thitung $>$ ttabel.

\section{Hasil dan Pembahasan}

Dalam mengukur hasil belajar siswa, peneliti menggunakan soal pilihan ganda yang berjumlah 24 soal. Soal tersebut diberikan sebanyak dua kali, yaitu pretest dan posttest. Sebelum kegiatan menggunakan permainan tradisional gobag sodor, diberi pretest dan setelah dilaksanakan permainan tradisional gobag sodor diberi posttest. Data tersebut dapat dilihat pada tabel berikut.

Tabel 1. Nilai Pretest dan Posttest

\begin{tabular}{ccc}
\hline Keterangan & Pretest & Posttest \\
\hline Nilai Terendah & 17 & 54 \\
Nilai Tertinggi & 92 & 100 \\
Rata-rata & 63,25 & 81 \\
\hline
\end{tabular}

Dalam mengukur hasil belajar siswa, peneliti menggunakan soal pilihan ganda yang berjumlah 24 soal. Soal tersebut diberikan sebanyak dua kali, yaitu pretest dan posttest. Sebelum kegiatan menggunakan permainan tradisional gobag sodor, diberi pretest dan setelah dilaksanakan permainan tradisional gobag sodor diberi posttest. Data tersebut dapat dilihat pada tabel berikut.

Berdasarkan tabel di atas, dapat dilihat, bahwa nilai pretest dan posttest jauh berbeda. Nilai tertinggi pada pretest sebesar 92 , dan nilai terendah sebesar 17 , dengan rata-rata sebesar 63,25. Sedangkan nilai tertinggi posttest sebesar 100, dan nilai terendah sebesar 54. Hal tersebut menunjukkan adanya peningkatan sebelum menggunakan permainan tradisional gobag sodor dan setelah menggunakan permainan tradisional gobag sodor yang dilihat dari nilai pretest dan posttest.

Uji normalitas awal dilakukan pada hasil pretest, dengan menggunakan uji liliefors. Hipotesis yang digunakan yaitu $\mathrm{Ho}$ : Sampel berasal dari data berdistribusi normal dan $\mathrm{Ha}$ : sampel tidak berasal dari data berdistribusi normal. Kriteria dalam uji normalitas adalah jika $\mathrm{L}_{0}<\mathrm{L}_{\text {tabel }}$ maka sampel berasal dari populasi yang berdistribusi normal. Dari hasil perhitungan nilai pretest dapat dilihat pada tabel berikut: 
Tabel 2. Uji Normalitas Pretest

\begin{tabular}{cccc}
\hline Kelas & $\mathrm{L}_{\circ}$ & $\mathrm{L}_{\text {tabel }}$ & Keterangan \\
\hline $\mathrm{V}$ & 0,1078 & 0,147667 & Normal \\
\hline
\end{tabular}

Berdasarkan Tabel 2 diatas, bahwa hasil perhitungan dari nilai pretes diperoleh dengan $n=36$, dan taraf $\alpha=0,05$, memiliki $L_{o}<L_{\text {tabel }}$ yaitu $0,1708<0,147667$, maka sampel berasal dari populasi berdistribusi normal.

Uji normalitas akhir dilakukan pada hasil posttest, dengan menggunakan uji liliefors. Hipotesis yang digunakan yaitu $\mathrm{Ho}$ : Sampel berasal dari data berdistribusi normal dan $\mathrm{Ha}$ : sampel tidak berasal dari data berdistribusi normal. Kriteria dalam uji normalitas adalah jika $\mathrm{L}_{0}<\mathrm{L}_{\text {tabel }}$ maka sampel berasal dari populasi yang berdistribusi normal. Dari hasil perhitungan nilai pretest dapat dilihat pada Tabel berikut:

Tabel 3. Uji Normalitas Posttest

\begin{tabular}{ccccc}
\hline Kelas & $\mathrm{L}_{0}$ & $\mathrm{~L}_{\text {tabel }}$ & Keterangan \\
\hline $\mathrm{V}$ & 0,0939 & 0,147667 & Normal \\
\hline
\end{tabular}

Berdasarkan Tabel 3, bahwa hasil perhitungan dari nilai posttest diperoleh dengan $n=36$, dan taraf $\alpha=0,05$, memiliki $L_{o}<L_{\text {tabel }}$ yaitu $0,0939<0,147667$, maka sampel berasal dari populasi berdistribusi normal.

Dalam penelitian ini, peneliti menilai dari afektif, psikomotorik dan kognitif. Penilaian Afektif, dilakukan dengan observasi secara langsung saat pembelajaran. Indikator dari penilaian afektif yaitu disiplin, percaya diri, bekerjasama, dan bertanggungjawab. Berikut Tabel ranah afektifnya.

Tabel 4. Ranah Afektif

\begin{tabular}{crcc}
\hline Pem & Nilai Tertinggi & Nilai Terendah & Rata-rata \\
\hline 1 & 87,5 & 43,75 & 67,53 \\
2 & 93,75 & 50 & 73,26 \\
$3 \& 4$ & 93,75 & 56,75 & 80,38 \\
5 & 93,75 & 68,75 & 82,63 \\
6 & 93,75 & 75 & 83,85 \\
\hline
\end{tabular}

Berdasarkan Tabel 4, selama proses pembelajaran menggunakan permainan tradisional gobag sodor, menunjukkan rata-rata siswa $\geq 70$. Di awal pembelajaran, nilai tertinggi siswa pada ranah ini, yaitu 87,5, dengan nilai terendah 67,53. Di akhir pembelajaran, nilai tertinggi mencapai 93,75 , dan nilai terendah 75 , sehingga mempengaruhi nilai rata-rata ranah afektif, yang semula 67,53 menjadi 83,85 .

Dalam penilaian aspek psikomotorik disini, disesuaikan dengan ketrampilan pada setiap mata pelajaran. Dimana ketrampilan tersebut juga menunjukkan rata-rata siswa $\geq 70$. Dengan disesuaikan keterampilan pada setiap mata pelajaran, siswa menjadi lebih aktif, dan terlihat kemampuan yang dimiliki di setiap siswa. Berikut nilai aspek psikomotorik.

Tabel 5. Ranah Psikomotorik

\begin{tabular}{lllll}
\hline No & Mata Pelajaran & Nilai Terendah & Nilai Tertinggi & Rata-rata \\
\hline \multirow{2}{*}{1} & 1.Bahasa Indonesia & 75 & 93,75 & 84,72 \\
& 2. IPA & 87,5 & 100 & 96,18 \\
2 & 1. Bahasa Indonesia & 68,75 & 93,75 & 81,59 \\
3 & 2. IPA & 68,75 & 93,75 & 85,76 \\
\hline
\end{tabular}




\begin{tabular}{|c|c|c|c|c|}
\hline & 2.IPS & 68,75 & 93,75 & 81,77 \\
\hline & 3. PPKn & 81,25 & 93,75 & 87,84 \\
\hline & 1.Bahasa Indonesia & 81,25 & 93,75 & 84,72 \\
\hline \multirow[t]{3}{*}{4} & 2.PPKn & 81,25 & 100 & 87,5 \\
\hline & 3. IPS & 75 & 93,75 & 85,41 \\
\hline & 1. Bahasa Indonesia & 75 & 100 & 87,78 \\
\hline \multirow[t]{2}{*}{5} & 2.SBdP & 81,25 & 100 & 89,58 \\
\hline & 3.IPA & 81,25 & 87,5 & 86,45 \\
\hline \multirow{2}{*}{6} & 1. SBdP & 81,25 & 93,75 & 88,54 \\
\hline & 2. PPKn & 75 & 100 & 85,24 \\
\hline
\end{tabular}

Berdasarkan Tabel tersebut, Ranah psikomotornya yaitu berdasarkan Kompetensi Dasar pada masing-masing mata pelajaran, yaitu Bahasa Indonesia, IPA, SBdP, IPS, dan PPKn. Pada pembelajaran pertama, terdapat mata pelajaran Bahasa Indonesia dengan indikator menulis pokok pikiran dari sebuah teks, dengan nilai terendah 75 , dan nilai tertinggi 87,5 , sehingga hasil rata-ratanya mencapai 78,81 . Selain itu terdapat mata pelajaran IPA, dengan indikator membuat contoh jaring-jaring makanan, nilai terendah siswa yaitu 75 dan nilai tertingginya 93,75 , sehingga hasil rata-ratanya mencapai 86,63 . Pada pembelajaran terakhir, terdapat mata pelajaran SBdP, dengan nilai terendah 81,25 , dan nilai tertinggi 93,75 , sehingga hasil rata-ratanya 88,54 . Selain itu terdapat mata pelajaran PPKn, dengan nilai terendah 81,25 dan nilai tertinggi 100 , sehingga memperoleh rata-rata 87,5 . Pada pembelajaran terakhir terdapat mata pelajaran Bahasa Indonesia, namun indikatornya hanya menunjukkan kesimpulan, jadi tidak diambil nilainya. Selain itu, pada pembelajaran ke dua juga tidak diambil nilai SBdP nya, karena indikatornya memperagakan tarian, dimana tarian itu ditarikan bersama-sama dan belum bisa diambil nilainya.

Selain itu ketuntasan belajar siswa secara individu dan klasikal mengalami peningkatan. Ketuntasan individu dapat dilihat dari data hasil belajar postest lebih baik daripada pretest. Dilihat dari perolehan nilai postest yang meningkat. Rata-rata nilai pretest sebesar 63,25, sedangkan rata-rata nilai posttest sebesar 81. Aspek ketrampilan yang menjadikan siswa pasif menjadi aktif dan aspek sikap yang menjadikan siswa mampu berpikir kritis untuk memecahkan masalah secara berama-sama, maka diperoleh hasil ketuntasan peserta didik yang meningkat. Sehingga dapat disimpulkan bahwa ketuntasan belajar siswa dapat meningkat setelah diberikan perlakuan menggunakan permainan tradisional gobag sodor..Ketuntasan belajar dapat dilihat pada tabel berikut.

Tabel 6. Ketuntasan Belajar

\begin{tabular}{lclll}
\hline Hasil & Jumlah Siswa & $\begin{array}{l}\text { Siswa Tuntas } \\
\text { Siswa Tidak } \\
\text { Tuntas }\end{array}$ & Persentase & Kategori \\
\hline Pretest & \multirow{2}{*}{36} & 31 & $86,11 \%$ & Tuntas \\
Posttest & 5 & 31 & $13,89 \%$ & Tidak Tuntas \\
& 36 & 5 & $86,11 \%$ & Tuntas \\
& 36 & $13,89 \%$ & Tidak Tuntas \\
\hline
\end{tabular}

Berdasarkan Tabel tersebut, terdapat 31 siswa yang tuntas, dengan begitu persentase ketuntasan belajar siswa mencapai 86,11\%. Menurut Depdiknas, untuk ketuntasan belajar klasikal, bahwa kelas dikatakan tuntas jika telah mencapai $85 \%$ dari seluruh siswa. Dengan hasil tersebut, dinyatakan tuntas secara klasikal.

Sebelum diberikan perlakuan (pretest) hanya ada beberapa peserta didik saja yang tuntas, sedangkan setelah diberikan perlakuan (post-test) sebagian besar peserta didik mendapatkan nilai tuntas. Jadi dapat disimpulkan bahwa ketuntasan belajar peserta didik meningkat setelah diberikan perlakuan menggunakan permainan tradisional gobag sodor.

Adapun penilaian pengetahuannya berupa hasil pekerjaan siswa tentang pembelajaran yang sudah dipelajari selama penelitian menggunakan permainan tradisional gobag sodor. 
Dalam penelitian ranah kognitif dilihat dari hasil posttest dengan kriteria ketuntasan 70 . Berikut hasil penilaian konitif.

Tabel 7. Ranah Kognitif

\begin{tabular}{lll}
\hline Nilai Terendah & Nilai Tertinggi & Rata-rata \\
\hline 54 & 100 & 81 \\
\hline
\end{tabular}

Berdasarkan Tabel di atas, dapat diketahui hasil ranah kognitif nilai tertinggnya, yaitu 100 , dan nilai terendahnya yaitu 54 , dengan rata-rata 81.

Uji Hipotesis pada penelitian ini yaitu menggunakan uji $t$, hal ini digunakan untuk menguji perbedaan hasil rata-rata nilai pretest dan posttest sebagai akibat dari penggunaan permainan tradisional gobag sodor. Hipotesis yang diujikan pada penelitian ini yaitu :

Ho : Tidak terdapat perbedaan nilai pretest dan posttest yang diperoleh setelah menggunakan permainan tradisional gobag sodor, dengan $t_{\text {hitung }}>t_{\text {tabel. }}$.

$\mathrm{Ha}$ : Ada perbedaan nilai nilai prettest dan posttest yang diperoleh setelah menggunakan permainan tradisional gobag sodor, dengan $t_{\text {hitung }}>t_{\text {tabel. }}$.

Rumus yang digunakan yaitu :

$$
t=\frac{M d}{\sqrt{\frac{\sum X^{2} d}{N(N-1)}}}
$$

Keterangan

Md = Mean dari perbedaan pre test dengan post test

$\Sigma_{X} 2 \mathrm{~d}=$ Jumlah kuadrat deviasi

$\mathrm{xd} \quad=$ Deviasi masing-masing subjek (d-Md)

$\mathrm{N} \quad=$ Subjek pada sampel

d.b. $=$ Ditentukan dengan $\mathrm{N}-1$

Berikut hasil uji t.

Tabel 8. Uji t

\begin{tabular}{ccccl}
\hline $\mathrm{Db}$ & Taraf Signifikan & $\mathrm{t}_{\text {tabel }}$ & $\mathrm{t}_{\text {hitung }}$ & Keterangan \\
\hline 35 & $5 \%$ & 1,684 & 5,903018 & $\mathrm{H}_{\mathrm{o}}$ ditolak \\
\hline
\end{tabular}

Berdasarkan Tabel diatas, bahwa rata-rata hasil pretest adalah 63,25 dan rata-rata hasil posttest adalah 81 , dengan $n=36$ dan diperoleh $t_{\text {hitung }} 5,903018$ dengan taraf $\alpha=5 \%$ dan $\mathrm{db}=\mathrm{N}-1=36-1=35$, diperoleh $\mathrm{t}_{\text {tabel }}=1,684$. Karena $t_{\text {hitung }}>\mathrm{t}_{\text {tabel }}$ maka $\mathrm{H}_{\mathrm{o}}$ ditolak. Jadi terdapat perbedaan nilai pretest dan nilai posttest, dengan hasil rata-rata nilai pretest 63,25 dan 81 . Dari hasil tersebut, terdapat kenaikan rata-rata nilai pretest dan nilai posttest sebesar $17,75 \%$. Sehingga disimpulkan bahwa ada perbedaan secara efektif, penerapan permainan tradisional gobag sodor terhadap hasil belajar subtema 3 Keseimbangan Ekosistem.

Meningkatnya hasil belajar tersebut, tidak terlepas dari peran guru yang dalam proses pembelajarannya aktif,kreatif, menyenangkan dan selalu memberikan kesempatan kepada siswa menemukan informasi yang mereka ingin tau. Hal itu sejalan dengan teori belajar kognitivistik, yang disampaiakan Bruner bahwa proses belajar akan berjalan dengan baik dan kreatif jika guru memberikan kesempatan kepada siswa untuk menemukan suatu aturan melalui contoh yang menggambarkan aturan yang menjadi sumbernya, sehingga melalui permainan tradisional gobag sodor ini, siswa mampu berpikir kritis menemukan informasi, yang menimbulkan rasa ingin tau siswa terhadap jawaban yang belum diketahui. Adapun kelebihan dari permainan tradisional gobag sodor, yaitu 1) Memberikan kegembiraan pada anak, 2) Mengasah kemampuan anak menyusun strategi untuk memenangkan permainan, 3) Melatih kerjasama anak dalam sebuah tim, 4) Melatih semangat juang anak untuk meraih 
kemenangan dalam permainan (semangat pantang menyerah), 5) Membuat anak menjadi aktif dalam pembelajaran,dan 6) Melatih daya pikir siswa melalui permainan yang didalamnya sudah dimodifikasi dengan ditambahkannya soal-soal. Kekurangan dari pelaksanaan ini, yaitu dalam pengkondisian, siswa masih ramai sendiri, dan terkadang sulit untuk diatur.

Terdapat banyak sekali nilai- nilai yang terdapat pada permainan tersebut, seperti nilai sosial skills, kerjasama dan kekompakan. Pada permainan gobag sodor juga terdapat nilai budaya seperti berkelompok, bekerjasama, dan menaati peraturan. Sehingga melalui permainan ini, anak dilatih secara fisik, bekerjasama, kekompakan,dan menaati aturan. Adapun langkah-langkah bermainnya yaitu membuat garis-garis penjagaan. Permainan tradisional gobag sodor sering disebut dengan galah asin, dimana permainan ini terdiri dari 2 kelompok, kelompok jaga dan kelompok lawan. Sebelum bermain siswa mendengarkan penjelasan materi dari guru, setelah selesai, anggota tim jaga menempati garis horizontal, dan garis vertikal (garis sodor). Tim lawan satu persatu harus masuk ke dalam kotak. Apabila tersentuh penjaga maka dianggap gugur. Saat berhasil masuk di kotak pertama, siswa harus menjawab soal yang sudah disediakan. Setelah selesai menjawab dilanjutkan masuk ke kotak selanjutnya dan mengambil soal kelompok, sampai bisa melewati garis terakhir. Durasi waktu dalam bermain permainan ini yaitu 10 menit. Untuk menentukan siapa yang juara, yaitu dilihat dari jumlah pemain yang bisa lolos ke garis finish dan durasi waktu tercepat sampai ke garis terakhir. Setelah kelompok jaga dan kelompok lawan bermain, masing-masing kelompok mengerjakan soal yang sudah diambil, begitu juga dengan kelompok yang lain. Apabila semua sudah mengerjakan, masing-masing kelompok mempresentasikan hasil diskusinya. Adapun hukuman yang kalah, yaitu menyanyikan lagu nasional yang mereka ketahui. Permainan tradisional gobag sodor yang dilakukan pada penelitian ini, sudah sedikit dimodifikasi. Adapun modifikasi yang dimaksud adalah, siswa harus menjawab soal setelah masuk di kotak pertama.

Dalam permainan tradisional gobag sodor sistem sosialnya yaitu 1) pembentukan kelompok oleh guru dan mendengarkan materi yang disampaikan oleh guru, 2) memulai permainan sesuai dengan urutan kelompok, 3) menjawab soal di dalam kotak yang sudah dilewatinya. 4) mengambil soal kelompok, 5) mengerjakan soal kelompok yang diperoleh, 6) menyampaikan hasil diskusi kelompok.

Prinsip reaksi dari permainan tradisional gobag sodor ini, yaitu guru sebagai fasilitator mengontrol dan membimbing siswa dalam proses pembelajaran terutama saat berdiskusi dalam mengerjakan soal yang diperoleh. Selain itu, guru berperan dalam mengatur jalannya permainan tradisional gobag sodor, dan sebagai juri/wasit. Terakhir, guru memberikan kesempatan kepada siswa untuk menyampaikan hasil diskusi, dan guru memberikan klarifikasi. Sistem pendukung dalam permainan ini berupa soal individu dan kelompok. Serta bahan ajar yang digunakan yaitu buku paket subtema 3 Keseimbangan Ekosistem.

Dampak instruksional adalah hasil belajar yang diperoleh secara langsung dengan cara mengarahkan siswa. Pada pemebelajaran dengan menggunakan permainan ini, siswa dapat memahami konsep-konsep materi pembelajaran yang disampaikan secara spesifik. Sedangkan dampak pengiringnya adalah kesadaran akan pilihan tentang jawaban atas pertanyaan yang diberikan guru, maupun pertanyaan dari soal yang ada dalam kotak permainan tersebut, serta kepekaan komunikasi dengan bekerjasama antar kelompoknya.

Secara umum hasil penelitian ini menunjukkan bahwa permainan tradisional gobag sodor efektif meningkatkan hasil belajar subtema 3 Keseimbangan ekosistem siswa kelas V. Dengan demikian apabila menerapakan menerapkan permainan gobag sodor sangatlah tepat untuk dapat meningkatkan hasil belajar subtema 3 Keseimbangan Ekosistem.

\section{Simpulan dan Saran}

Dari hasil penelitian ini dapat ditarik kesimpulan bahwa permainan tradisional gobag sodor evektiv untuk meningkatkan hasil belajar subtema 3 Keseimbangan Ekosistem pada 
siswa kelas V SD N Wonolopo 02. Hal tersebut dibuktikan dengan 1) terdapat perbedaan pretest dan posttes dibuktikan dengan hasil uji t thitung sebesar 5,903018 > ttabel 1,684 pada taraf signifikan 5\%, 2) Rata-rata nilai sikap (afektif) dan keterampilan (psikomotorik) siswa juga meningkat dengan menggunakan permainan tradisional gobag sodor, dimana hasilnya lebih dari KKM (Ketuntasan Kriteria Minimal) yaitu 70. Rata-rata Nilai sikap mencapai 83,85 . Sedangkan rata-rata nilai keterampilan disetiap mata pelajaran yang menunjukkkan lebih dari 70. 3) Ketuntasan belajar individu dilihat dari nilai posttest lebih baik dari nilai pretest, terdapat 31 siswa tuntas, dan 5 siswa yang belum tuntas. Ketuntasan belajar klasikal mencapai 86,11\%. Dari hasil penelitian tersebut, dapat disimpulkan bahwa permainan tradisional gobag sodor efektif terhadap hasil belajar subtema 3 keseimbangan ekosistem siswa Kelas V SD N Wonolopo 02.

Berdasarkan temuan penelitian, saran-saran yang perlu disampaikan adalah pertama bagi siswa, dimana siswa harus tetap mengenal dan melestarikan nilai-nilai budaya lokal yang dimilikinya dalam hal ini permainan tradisional. Karena elemen-elemen yang ada dalam permainan tradisional ini sangat berguna untuk meningkatkan hasil belajar yang maksimal. Selain itu siswa harus selalu aktf dan kreatif, supaya pembelajarannya lebih bermakna. Kedua bagi guru, guru harus selalu memberikan alternatif teknik pengajaran yang lain kepada siswa dan mampu melestarikan budaya lokal yang ada dalam setiap pembelajaran yang dilakukan, salah satunya dengan permainan tradisional ggobag sodor. Selain itu, permainan tersebut dapat dijadikan sebagai model ataupun metode pembelajaran siswa, sehingga pembelajarannya membuat siswa aktif, kreatif, dan menyenangkan. Bagi Sekolah diharapkan selalu mendukung guru, untuk selalu mengajarkan permainan tradisional karena banyak sekali permainan tradisional yang bisa digunakan untuk media pembelajaran. Penggunaan permainan tradisional membutuhkan manajemen waktu dan pengelolaan yang baik sehingga diperlukan perencanaan pembelajaran yang tepat agar penggunaan waktu lebih efektif.

\section{Daftar Pustaka}

Achroni, Keen. 2012. Mengoptimalkan Tumbuh Kembang Anak Melalui Permainan Tradisional. Jogjakarta: Javalitera.

Arifin, Zainal.2016.Evaluasi Pembelajaran.Bandung: PT Remaja Rosdakarya

Arikunto, Suharsini. 2013. Prosedur Penelitian Suatu Pendekatan Praktik. Jakarta: Rineka Cipta.

Arikunto, Suharsini. 2016. Manajemen Penelitian. Jakarta: Rineka Cipta.

Arikunto,Suharsimi.2013.Dasar-dasar Evaluasi Pendidikan Edisi 2. Jakarta: Bumi Aksara.

Devi, Rachma Pratiwi. Pengaruh Permainan Tradisional Gerobak sodor Terhadap Keterampilan Sosial Anak Kelompok B Di Paud Islam Terpadu Baiturrahman Kecamatan pakusari Kabupaten Jember Tahun Pelajaran 2017/2018.

Hakim, Arief Rahman. 2017.Evektivitas Permaianan Tradisional Gobag Sodor Untuk Pembelajaran IPS Kelas IV Sekolah Dasar.Malang: Universitas Kanjuruhan Malang.

Huda, Anwarul. 2015.Pengaruh Permainan Tradisional Gobag Sodor terhadap Kecerdasan Interpersonal dengan Teman Sebaya pada Anak-anak. Jurnal Psikologi Universitas UIN Maulana Malik Ibrahim Malang Vol.4 No.1 Tahun 2015.

Kadir, Abd dan Asrohah Hanun. 2014. Pembelajaran Tematik. Jakarta: Rajawali Pers. 
Kurniati, Euis. 2016. Permainan Tradisional Dan Perannya dalam Mengembangkan Keterampilan Sosial Anak. Jakarta: Kencana.

Kurniawan, Deni. 2014. Pembelajaran Terpadu Tematik. Bandung: Penerbit Alfabeta.

Komsiyah, Indah.2013. Teori Belajar dan Pembelajaran di Sekolah Dasar. Jakarta: Kencana.

Linggar, Siti. 2010. Ayo Lestarikan Permainan Tradisional. Jakarta: Karya Mandiri Nusantara.

Toha, Mohammad.2017. Pengembangan model permainan tradisional geprek kempung dan gobag sodor untuk pembelajaran ilmu pengetahuan sosial di sekolah dasar. Jurnal IImu Pendidikan Universitas Negeri Malang Vol.2 No.1 Tahun 2017.

M. fajar, Rivanny. "The Values Of Balogo Traditional Games As The Source Of Social Science Education (IPS) Learning. ATLANTIS PRESS.

Mulyasa.2015. Guru dalam Implementasi Kurikulum 2013. Bandung: PT Remaja Rosdakarya Offset.

Siregar, Eveline \& Nara, Hartini. 2014. Teori Belajar dan Pembelajaran. Bogor: Penerbit Ghalia Indonesia.

Slameto. 2010. Belajar dan Faktor-faktor yang Mempengaruhinya. Jakarta: Rineka Cipta.

Soegeng, A.Y. 2018. Filsafat Pendidikan. DI Yogyakarta : Magnum Pustaka Utama.

Sudjana, Nana. 2014. Penilaian Hasil Proses Belajar Mengajar. Bandung: PT Remaja Rosdakarya.

Sugiyono. 2016. Metode Penelitian Pendidikan Pendekatan Kuantitatif, Kualitatif, dan R\&D. Bandung: Alfabeta

Susanto, Ahmad. 2013. Teori Belajar dan Pembelajaran di Sekolah Dasar.Jakarta: Kencana.

Tedjasaputra, Mayke.S. 2007. Bermain, Mainan, dan Permainan. Jakarta: PT Grasindo.

Warsita, Bambang. 2008. Teknologi Pembelajaran Landasan \& Aplikasinya. Jakarta: Rineka Cipta. 